\title{
Investigation on Quantitative Index of Chilling Injury in Cucumber Fruit Based on The Electrolyte Leakage and Malondialdehyde Content
}

\author{
Khandra Fahmy", Kohei Nakano*, Fidela Violalita ${ }^{1}$ \\ \# Department of Agricultural Engineering, Faculty of Agricultural Technology, Andalas University, 25163, Indonesia \\ * Faculty of Applied Biological Sciences Gifu, University, 1-1 Yanagido, Gifu, 5011193 Japan \\ E-mail: knakano@gifu-u.ac.jp \\ ${ }^{1}$ Department of Food Technology, Agricultural Polytechnic State of Payakumbuh- Indonesia
}

\begin{abstract}
The objective of this study was to investigate the quantitative index of CI in cucumber fruit based on electrolyte leakage and MDA content. The results show that a rapid increase in electrolyte leakage was observed after 4 days storage at $5^{\circ} \mathrm{C}$; while of fruit stored at $20^{\circ} \mathrm{C}$ was maintained at the same level. On other hand, significant difference in MDA equivalent was not found between cucumber fruit stored at $5^{\circ} \mathrm{C}$ and $20^{\circ} \mathrm{C}$; nevertheless, the MDA equivalent of fruit stored at $5^{\circ} \mathrm{C}$ was higher than that of stored at $20^{\circ} \mathrm{C}$. Since the electrolyte leakage and MDA equivalent are related with oxidative stress which they increased in response to storage at low-temperature, thus they can be used as an indicator of cell membrane damage caused by CI in cucumber fruit.
\end{abstract}

Keywords - cucumber fruit, low-temperature, chilling injury, electrolyte leakage, malondialdehyde

\section{INTRODUCTION}

Cucumber fruit is susceptible to chilling injury (CI) characterized as surface pitting, dark watery patches and increased susceptibility to decay [1]. CI is a physiological disorder induced by low-temperature but non-freezing temperatures on chilling-sensitive products.

Various methods have been developed to reduce CI in cucumber fruit $[1 ; 2 ; 3 ; 4]$, but the mechanism involved in the CI of cucumber fruit are still not clear. CI is believed to be initiated by dysfunction of cell membranes at lowtemperatures. Change in properties of cell membranes at a low-temperature is thought to be primary event of CI (5). CI disrupts the balance of reactive oxygen species (ROS) metabolism, leading to their accumulation. The accumulation of ROS induces the lipid peroxidation, cause solute of leaking and accumulation of malondialdehyde (MDA) content [3; 4], leading to damage of cell membranes. Marangoni et al. (6) also reported the sequence of alteration of membranes caused by CI.

Therefore, the investigation of CI index in internal level of fruit requires for ensuring of damage caused by CI. The electrolyte leakage and MDA assessment has been used to measure CI indication [3; 4]. Thus, the objective of this study was to investigate the quantitative index of CI in cucumber fruit based on electrolyte leakage and MDA assessment. Fruits were stored at chilling-temperature and non-chilling-temperature for 6 day. The electrolyte leakage and MDA was evaluated every $2^{\text {nd }}$ of storage. In addition, the kinetics of ion leakage from excised mesocrap discs of cucumber fruit was also determined.

\section{MATERIALS AND METHODS}

\section{A. Plant materials and storage condition}

Cucumbers fruit (Cucumis sativus L.) at commercial maturity were purchased from Kanesue supermarket in Gifu city, Japan. Thirty fruit were divided into two lots and stored at $5^{\circ} \mathrm{C}$ (chilling-temperature) and at $20^{\circ} \mathrm{C}$ (non-chilling temperature) for 6 days. Fruits were packaged in polyethylene bags to prevent water loss during storage. Samples were taken every $2^{\text {nd }}$ days to check electrolyte leakage and MDA content. The mesocarp of cucumber was cut into small cubes, frozen in liquid nitrogen quickly and stored at $-50^{\circ} \mathrm{C}$ (NF-300SF, Nihon Freezer, Japan) until analysis.

\section{B. Electrolyte leakage}

Electrolyte leakage was assessed using a method described by Saltveit [7] with some modifications. Mesocarps of cucumber fruit from different parts (top, medium, bottom) were excised with a stainless steel cork 
borer (diameter $\square 11 \mathrm{~mm}$ ) and then cut into $4 \mathrm{~mm}$ thick discs by using a sharp knife. The discs were washed in deionised water thrice for $1 \mathrm{~min}$ each time and blotted dry, and 3 selected discs were placed into $50 \mathrm{~mL}$ centrifuge tubes with $20 \mathrm{~mL}$ of $0.2 \mathrm{M}$ mannitol. The tubes were shaken at 100 cycles/min in a water bath incubator (Personal-11, Taitec, Japan). Conductivity was measured with a conductivity meter (ES-51, Horiba, Japan) every $2 \mathrm{~min}$ for $1 \mathrm{~h}$ and the less frequently for $240 \mathrm{~min}$. The tubes were then capped, and frozen and thawed twice over the next few days. The total conductivity of the solution was measured after an additional $0.5 \mathrm{~h}$ of shaking. Individual conductivity readings were converted to the percentage of total conductivity. Ion efflux data from the excised mesocrap disc of cucumber fruit was analyzed to find $\mathrm{C}_{\mathrm{f}}, \mathrm{D} 2, \mathrm{~K}_{\mathrm{f}}, \mathrm{E}_{\mathrm{f}}, \mathrm{D} 3, \mathrm{~K}_{\mathrm{s}}$ and $\mathrm{E}_{\mathrm{s}}$. Root mean square error (RMSE) was calculated to measure the difference between the predicted values by an equation and the values actually observed.

\section{Malondialdehyde content}

MDA content was determined according to the method of Hodges et al. [8] with some modifications. Mesocarp tissue $(1 \mathrm{~g})$ of cucumber fruit was homogenised in $10 \mathrm{~mL}$ of $80 \%$ (v/v) ethanol along with $0.5 \mathrm{~g}$ inert sand using a mortar and pestle, followed by centrifugation at $3,000 \times \mathrm{g}$ at $4^{\circ} \mathrm{C}$ for 10 min. A $1-\mathrm{mL}$ aliquot of the appropriately diluted sample was added either to $1 \mathrm{~mL}$ of $0.65 \%$ thiobarbituric acid (TBA) solution containing $20.0 \%(\mathrm{w} / \mathrm{v})$ trichloroacetic acid (TCA) and $0.01 \%$ butylatedhydroxytoluene (BHT) or to a solution containing $20.0 \%$ (w/v) TCA and $0.01 \%$ BHT. The samples were then mixed vigorously, boiled for $25 \mathrm{~min}$, cooled in an ice bath immediately and centrifuged at $3,000 \times \mathrm{g}$ at $4^{\circ} \mathrm{C}$ for $10 \mathrm{~min}$. Absorbances at $532 \mathrm{~nm}, 440 \mathrm{~nm}$ and $600 \mathrm{~nm}$ were recorded using a spectrophotometer (UV1600, Shimadzu, Japan). The MDA equivalents were calculated by the following equations

$$
\begin{aligned}
& {\left[\left(A 532_{+3 B A}-A 600_{+\pi B A}\right)-\left(A 532_{-T B A}-A 600_{-T B A}\right)\right]} \\
& {\left[\left(\mathrm{A440}+7 \mathrm{TEA}-A_{+7 E A}\right) \times 0.057 \mathrm{I}\right]} \\
& \text { MDA equivalents }\left(\text { mol } m I^{l}\right)=((A-B) / 157000) \times \text {. }
\end{aligned}
$$

\section{Statistical analysis}

All experiments were repeated at least once with similar results. Appropriate data were combined and means and standard error were calculated from the data. Statistical significance was determined by subjecting the mean values to analysis of variance and means were compared by Tukey's test at the 5\% level of significance using R 2.15.2 (R Foundation).

\section{RESULTS AND DISCUSSION}

Figure 1 shows the percentage of electrolyte leakage from excised mesocrap discs of cucumber fruit stored at $5^{\circ} \mathrm{C}$ and at $20^{\circ} \mathrm{C}$ for 6 days. The electrolyte leakage of fruit stored at $20^{\circ} \mathrm{C}$ did not increase significantly during period of storage. On other hand, the increase of electrolyte leakage of fruit stored at $5^{\circ} \mathrm{C}$ was suppressed up to day 4 , after that, it increased significantly. Particularly, it was significantly higher than that of fruits stored at $20^{\circ} \mathrm{C}$ on day 6 . Significant increase of electrolyte leakage during storage at lowtemperature has been used as an indicator of CI, as reported for cucumber fruit $[1 ; 3 ; 4 ; 9]$, tomato $[7 ; 10 ; 11 ; 12]$ and lemon basil [13]. Parkin et al. [5] reported that a bulk lipidphase membrane transition occurs in chilling sensitive product during low-temperatures storage. In such a condition, the bulk lipid-phase membrane transforms from liquidcrystalline phase to solid gel-phase lipids. As a result the permeability or leakiness of cellular membranes increased. In contrary, the bulk lipid-phase is maintained in the liquidcrystalline state at non-chilling-temperature storage. Likewise, Wilson [14] reported that the membrane permeability at chilling temperatures have shown an increase in the rate of electrolyte leakage from chilling-sensitive product.

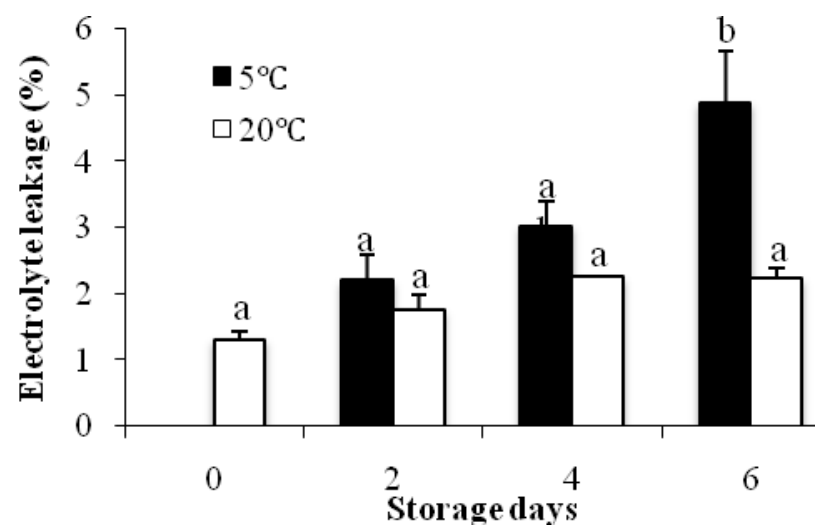

Fig. 1. Percentage of electrolyte leakage from excised mesocrap discs of cucumber fruit during storage at $5^{\circ} \mathrm{C}$ (chilling-temperature) and at $20^{\circ} \mathrm{C}$ (non-chilling temperature) for 6 days. Vertical lines represent standard error. Values with different letters were significantly different at $\mathrm{P}<0.05$.

Figure 2 shows the representative analysis of ion efflux data from excised mesocrap discs of cucumber fruit to find $\mathrm{C}_{\mathrm{f}}, \mathrm{D} 2, \mathrm{~K}_{\mathrm{f}}, \mathrm{E}_{\mathrm{f}}, \mathrm{D} 3, \mathrm{~K}_{\mathrm{s}}$ and $\mathrm{E}_{\mathrm{s}}$. These components were described by the combination of two exponential equations of the form $E_{f}=C_{f}\left(1-e^{E_{f}}\right)$ from a 'fast' extra-cellular apoplastic reservoir of ion and $E_{s}=C_{s}\left(1-e^{N_{s}}\right)$ from a 'slow' cellular symplastic reservoir. Since the concentration of ion is expressed as the percentage of total conductivity, the $\mathrm{C}_{\mathrm{f}}+\mathrm{C}_{\mathrm{s}}$ is equal to 100 [11]. D1 was the original data that calculated from the individual reading and then zeroed by subtracting the zero time value from all subsequent of readings to give the D1 in percentage of total conductivity. A linear equation was obtained from D1 by starting with data from 90 to $240 \mathrm{~min}$, which was chosen when coefficient of determination $\left(\mathrm{R}^{2}\right)$ was 0.99 . The intercept of the linear equation gave the value of $C_{f}$ i.e. the percentage of the total conductivity in 'fast' compartment. The D2 was calculated using the slope of linear equation for each sample time and then subtracted from the D1. The time constant from the 'fast' compartment $\left(\mathrm{K}_{\mathrm{f}}\right)$ was obtained by linearizing the D2 data set. The exponential equation $\left(E_{f}\right)$ was calculated for each sample time and then fitted to the D2 data set (RMSE = 0.07). The values from $E_{f}$ for each sample time were subtracted from the D1 to give the D3 data set. The D3 data set was linearized to obtain the time constant from 'slow' compartment $\left(\mathrm{K}_{\mathrm{s}}\right)$. The exponential equation $\left(\mathrm{E}_{\mathrm{s}}\right)$ was calculated for each sample time and then fitted to the D3 
data set $(\mathrm{RMSE}=0.09)$. Combination of $\mathrm{E}_{\mathrm{f}}$ and $\mathrm{E}_{\mathrm{s}}$ for each sample time was fitted to the D1 data set, and the prediction was very close to the D1 data set $(\mathrm{RMSE}=0.09)$.

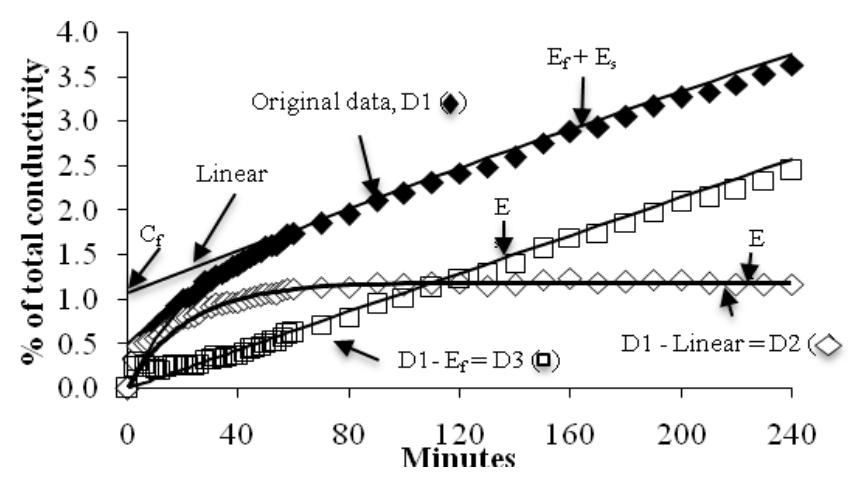

Fig. 2. Representative analysis of ion efflux data from excised mesocrap disc of cucumber fruit held in a $0.2 \mathrm{M}$ mannitol solution to find $\mathrm{C}_{\mathrm{f}}, \mathrm{D} 2, \mathrm{~K}_{\mathrm{f}}$, $E_{\mathrm{f}}, \mathrm{D} 3, \mathrm{~K}_{\mathrm{s}}$ and $\mathrm{E}_{\mathrm{s}}$. Root mean square error (RMSE) was 0.09, 0.07 and 0.09 for $D 1$ versus $E_{f}+E_{s}$, D2 versus $E_{f}$ and $D 3$ versus $E_{s}$, respectively.

Figure 3 shows the percentage of total conductivity in the 'fast' compartment $\left(\mathrm{C}_{\mathrm{f}}\right)$ from excised mesocrap discs of cucumber fruit stored at $5^{\circ} \mathrm{C}$ and at $20^{\circ} \mathrm{C}$ for 6 days. No significant increase of $\mathrm{C}_{\mathrm{f}}$ values was observed of fruit stored at $20^{\circ} \mathrm{C}$ during period of storage. On other, the $\mathrm{C}_{\mathrm{f}}$ values of fruit stored at $5^{\circ} \mathrm{C}$ did not increase significantly up to day 4 , after that, the $\mathrm{Cf}$ values increased significantly. Particularly, the $\mathrm{C}_{\mathrm{f}}$ values was significantly higher than that of fruit stored at $20^{\circ} \mathrm{C}$ on day $6 . \mathrm{C}_{\mathrm{f}}$ represents the apoplastic concentration of diffusible ion which the values increase after remaining constant for several day at low-temperature storage. It has been reported the rapid increase of $\mathrm{Cf}$ from mature green tomato is observed after 4 days of storage at $2.5^{\circ} \mathrm{C}$ for 24 days [11].

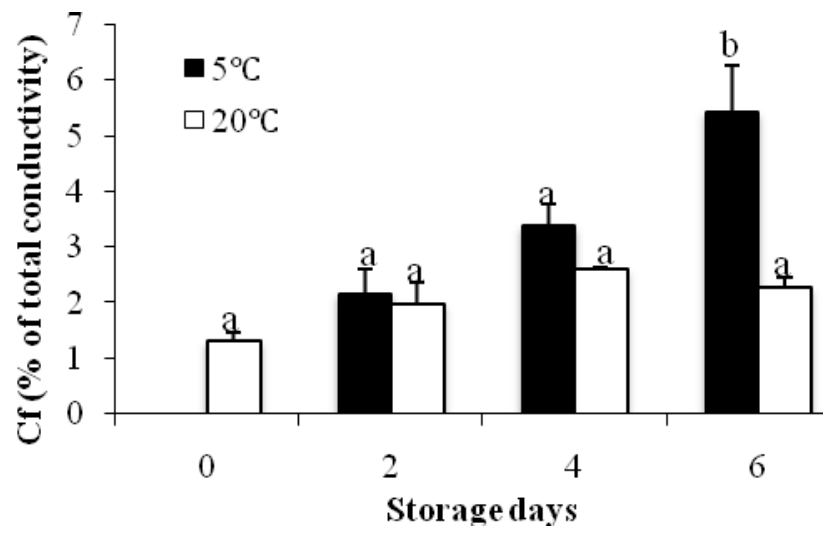

Fig. 3. The percentage of total conductivity in the 'fast' compartment $\left(\mathrm{C}_{\mathrm{f}}\right)$ from excised mesocrap discs of cucumber fruit stored at $5^{\circ} \mathrm{C}$ (chillingtemperature) and at $20^{\circ} \mathrm{C}$ (non-chilling temperature) for 6 days. Vertical lines represent standard error. Values with different letters were significantly different at $\mathrm{P}<0.05$

Figure 4 shows the coefficient of fast compartment $\left(\mathrm{K}_{\mathrm{f}}\right)$ of the kinetic analysis of electrolyte leakage from excised mesocrap discs of cucumber fruit stored at $5^{\circ} \mathrm{C}$ (chillingtemperature) and at $20^{\circ} \mathrm{C}$ (non-chilling temperature) for 6 days. The $\mathrm{K}_{\mathrm{f}}$ values were maintained at the same level for both of temperatures tested during period of storage where significant difference in $K_{f}$ values was not found among temperatures tested. The coefficient $\mathrm{K}_{\mathrm{f}}$ describes the rate of ion leakage from the apoplastic compartment (i.e. outside the cellular membrane), and it remained relatively constant during chilling temperature [7]. Saltveit [11] reported that the $\mathrm{K}_{\mathrm{f}}$ values from excised of green mature tomato did not change during storage at $2.5^{\circ} \mathrm{C}$ for 24 days. Similar finding also reported that significant increase in $\mathrm{K}_{\mathrm{f}}$ did not show from excised of tomato during placed at $2.5^{\circ} \mathrm{C}$ for 14 day [12].

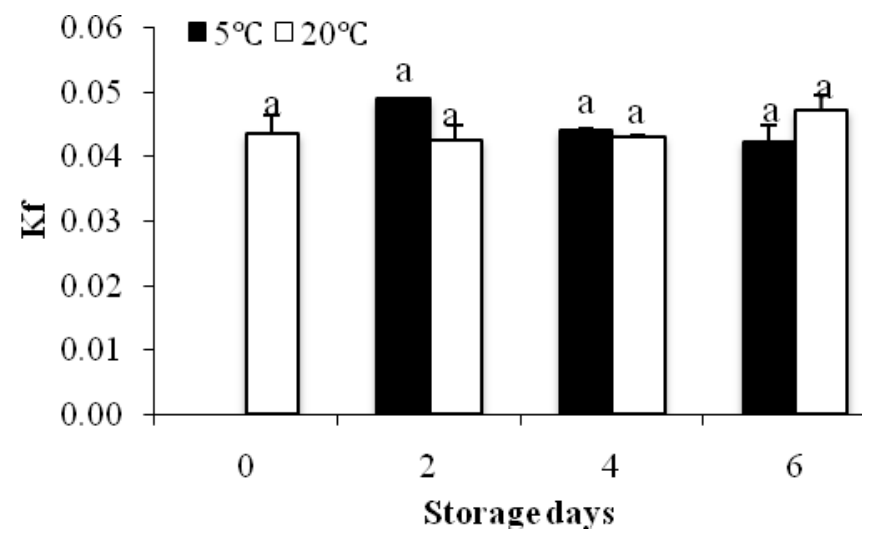

Fig. 4. The fast compartment coefficient $\left(\mathrm{K}_{\mathrm{f}}\right)$ of the kinetic analysis of electrolyte leakage from excised mesocrap discs of cucumber held in a $0.2 \mathrm{M}$ mannitol solution stored at $5^{\circ} \mathrm{C}$ (chilling-temperature) and at $20^{\circ} \mathrm{C}$ (nonchilling temperature) for 6 days. Vertical lines represent standard error. Values with different letters were significantly different at $\mathrm{P}<0.05$.

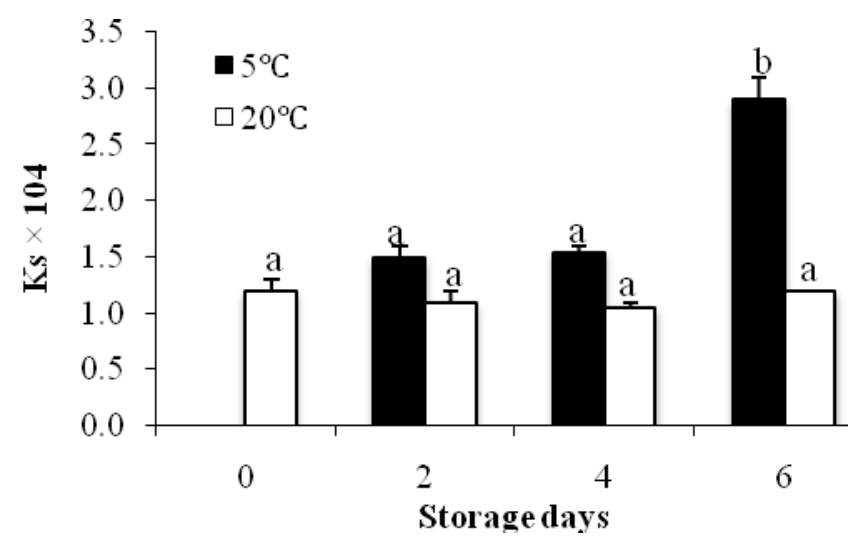

Fig. 5. The slow compartment coefficient $\left(\mathrm{K}_{\mathrm{s}}\right)$ of the kinetic analysis of electrolyte leakage from excised mesocrap discs of cucumber fruit held in a $0.2 \mathrm{M}$ mannitol solution stored at $5^{\circ} \mathrm{C}$ (chilling-temperature) and at $20^{\circ} \mathrm{C}$ (non-chilling temperature) for 6 days. Vertical lines represent standard error. Values with different letters were significantly different at $\mathrm{P}<0.05$.

Figure 5 shows the coefficient of slow compartment $\left(\mathrm{K}_{\mathrm{s}}\right)$ of the kinetic analysis of electrolyte leakage from excised mesocrap discs of cucumber fruit stored at $5^{\circ} \mathrm{C}$ (chillingtemperature) and at $20^{\circ} \mathrm{C}$ (non-chilling temperature) for 6 days. $\mathrm{K}_{\mathrm{s}}$ values was maintained at the same level during period of storage when fruit were stored at $20^{\circ} \mathrm{C}$. $\mathrm{K}_{\mathrm{s}}$ values of fruit stored at $5^{\circ} \mathrm{C}$ increased significantly on day 6 after remaining relatively constant for the first 4 days of chilling, which the $K_{s}$ values was higher significantly than that of fruit stored at $20^{\circ} \mathrm{C}$. The coefficient $\mathrm{K}_{\mathrm{s}}$ describes the rate of ion leakage from symplastic compartment (i.e. across the cellular membrane), which the values increase during 
storage at chilling temperatures. Saltveit [11] found a similar trend of the change $K_{s}$ value with $C_{f}$ value, which rapid increase on $\mathrm{K}_{\mathrm{s}}$ is shown after 4 days of storage, and these trends correspond to the $\mathrm{C}_{\mathrm{f}}$ and $\mathrm{K}_{\mathrm{s}}$ obtained in this study.

Figure 6 shows the MDA equivalent of cucumbers fruit during storage at $5^{\circ} \mathrm{C}$ and $20^{\circ} \mathrm{C}$ for 5 days under ambient air. The MDA equivalent increased for both temperatures tested during period of storage, but significant difference was not found among both of temperatures tested. Although significant difference was not found among them, however, the MDA equivalent of fruit stored at chilling temperature was higher than those of fruit stored at non-chilling temperature during period of storage. As final product of lipid peroxidation, the MDA is often used as index of cell damage under environmental stress, as reported for cucumber fruit $(3 ; 4 ; 15)$ and pears [16]. Low temperaturesinduced changes in the properties of cell membranes due to change in physical state of membrane lipids (membrane phase change). As a result increases the production of reactive oxygen species (ROS), leading to damage of the cell membranes [17]. Mao et al. [3] indicated that CI might mediate catabolic reaction targeting cell membranes.

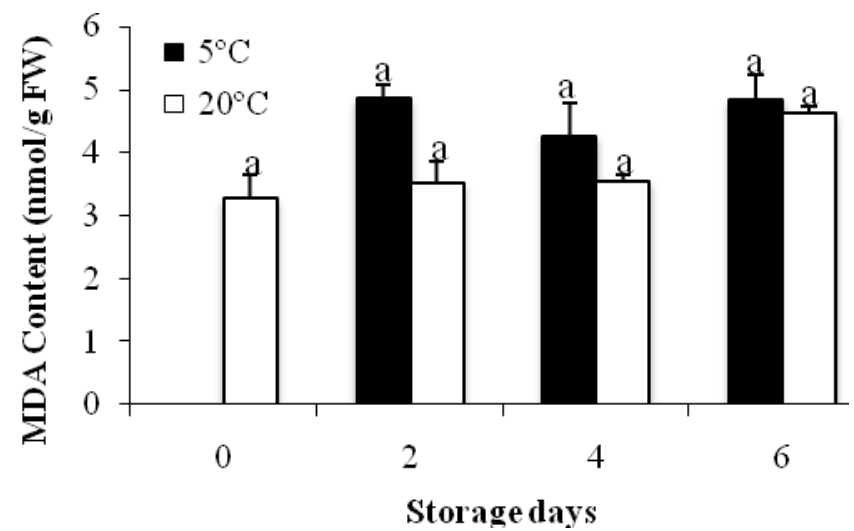

Fig. 6. The MDA equivalent of cucumber fruit during storage at $5^{\circ} \mathrm{C}$ (chilling-temperature) and at $20^{\circ} \mathrm{C}$ (non-chilling temperature) for 6 days. Vertical lines represent standard error. Values with different letters were significantly different at $\mathrm{P}<0.05$.

\section{CONCLUSIONS}

In this study, the investigation of CI of cucumber fruit based on electrolyte leakage and MDA equivalent was carried out. A rapid increase in electrolyte leakage was observed after 4 days storage at $5^{\circ} \mathrm{C}$; while of fruit stored at $20^{\circ} \mathrm{C}$ was maintained at the same level. On other hand, significant difference in MDA equivalent was not found between cucumber fruit stored at $5^{\circ} \mathrm{C}$ and $20^{\circ} \mathrm{C}$, nevertheless, the MDA equivalent of fruit stored at $5{ }^{\circ} \mathrm{C}$ was higher than that of stored at $20^{\circ} \mathrm{C}$. Since the electrolyte leakage and MDA equivalent are related with oxidative stress, which they increase in response to storage at low-temperature, thus the electrolyte leakage and MDA equivalent can be used as an indicator of cell membrane damage caused by $\mathrm{CI}$ in cucumber fruits.

\section{REFERENCES}

[1] Cabrera, R.M., Saltveit, M.E. (1990). Physiological response to chilling temperatures of intermittently warmed cucumber fruit. Ameri. Soc. Hortic. Sci., 115, 256-261.

[2] Wang, C.Y., and Qi, L. (1997). Modified atmosphere packaging alleviates chilling injury in cucumbers. Postharvest Biol. Technol., 10, 195-200.

[3] Mao, L., Pang, H., Wang, G., and Zhu, C. (2007a). Phospholipase D and lipoxygenase activity of cucumber fruit in response to chilling stress. Postharvest Biol. Technol., 44, 42-47.

[4] Yang, H., Wu, F., and Cheng, J. (2011). Reduced chilling injury in cucumber by nitric oxide and the antioxidant response. Food Chem., 127, 1237-1242.

[5] Parkin, K.L., Maranggoni, A., Jackman, R.L., Yada, R.D., and Stanley, D.W. (1989). Chilling injury. A review of possible mechanisms. Food Biochem., 13, 127-153.

[6] Marangoni, A.G., Palma, T., and Stanley, D.W. (1996). Membrane effects in postharvest physiology. Postharvest Biol. Technol., 7, 193217.

[7] Saltveit, M.E. (2002). The rate of ion leakage from chilling-sensitive tissue does not immediately increase upon exposure to chilling temperatures. Postharvest Biol. Technol., 26, 295-304.

[8] Hodges, D.M., DeLong, J.M., Forney, C.F., and Prange, R.K. (1999). Improving the thiobarbituric acid-reactive-substances assay for estimating lipid peroxidation in plant tissues containing anthocyanin and other interfering compounds. Planta 207, 604-611.

[9] Hakim, A., Purvis, A.C., and Mullinix, B.G. (1999). Differences in chilling sensitivity of cucumber varieties depend on storage temperature and the physiological dysfunction evaluated. Postharvest Biol. Technol., 17, 97-104.

[10] Palma, T., Marangoni, A.G., and Stanley, D.W. (1995). Environmental stresses affect tomato microsomal membrane function differently than natural ripening and senescence. Postharvest Biol. Technol., 6, 257-273.

[11] Saltveit, M.E. (2005). Influence of heat shock on the kinetic of chilling-induced ion leakage from tomato pericarp discs. Postharvest Biol. Technol., 36, 87-92.

[12] Luengwilai, K., Beckles, D.M., and Saltveit, M.E. (2012). Chillinginjury of harvested tomato (Solanum lycopersicum L.) cv. MicroTom fruit is reduced by temperature pre-treatments. Postharvest Biol. Technol. 63: 123-128.

[13] Wongsheree, T., Ketsa, S., and van Doorn, W.G. (2009). The relationship between chilling injury and membrane damage in lemon basil (Ocimum $\times$ citridourum) leaves. Postharvest. Biol., Technol. 51, 91-96.

[14] Wilson, J.M. (1979). Drought resistance as related to low temperature stress. In: Lyons, J.M., Graham, D., Raison, J.K. [eds.], Low temperature stress in crop plants, pp. 47-65. Academic Press, New York.

[15] Karakaş, B., and Yıldız, F. (2007). Peroxidation of membrane lipids in minimally processed cucumbers packaged under modified atmospheres. Food Chem., 100, 1011-1018.

[16] Larrigaudiere, C., Lentheric, I., Pintó, E., and Vendrell, M. (2001). Short-term effects of air and controlled atmosphere storage on antioxidant metabolism in conference pears. J. Plant Physiol., 158, 1015-1022.

[17] Imahori, Y., Takemura, M., and Bai, J. (2008). Chilling-induced oxidative stress and antioxidant responses in mume (Prunus mume) fruit during low temperature storage. Postharvest Biol. Technol., 49, 54-60 